\title{
PARTISIPASI PETANI PADI DALAM PELAKSANAAN PROGRAM PENINGKATAN PRODUKSI BERAS NASIONAL (P2BN) DI KECAMATAN SEPUTIH MATARAM LAMPUNG TENGAH
}

\author{
(The Participation of Rice Farmer in Implementation of National Rice Production Improvement Program \\ (P2BN) in Subdistricts Seputih Mataram Lampung Tengah Regency)
}

I Made Thresna Yama, Sumaryo Gitosaputra, Tubagus Hasanuddin

Jurusan Agribisnis, Fakultas Pertanian, Universitas Lampung, Jl. Prof. Dr. Soemantri Brojonegoro No.1 Bandar Lampung 35141, Telp. 085769619659, e-mail: madethresnayamay@gmail.com

\begin{abstract}
This study aims to find out the performance of the P2BN Program, to find out the level of rice farmers' participation in the P2BN Program and to study the factors that influence the rice farmer participation in the $P 2 B N$ Program. The research method used is a survey. The location is determined intentionally in subdistricts Seputih Mataram Central Lampung regency in November - December 2016. Sample units are 95 rice farmers. The analyses of data used descriptive method and used Rank-Spearman correlation to test the hypothesis. The results of the research showed that: the performance of P2BN Program in planning, implementation, profit utilization, and evaluation in Seputih Mataram Subdistrict of Central Lampung Regency is in high classification, The level of rice farmer participation in P2BN Program is in middle classification. Factors significantly related to farmers' participation in implementation of P2BN Program are knowledge on P2BN Program and social support. Meanwhile, the large of arable land, income level, and facility received by farmers do not have relationship with their participation in the P2BN Program.
\end{abstract}

Key words: P2BN Program, participation, Seputih Mataram

\section{PENDAHULUAN}

Beras adalah makanan pokok masyarakat di Indonesia. Seiring meningkatnya permintaan beras sehingga tidak ada cara lain selain mengimpor beras dari luar negeri. Salah satu upaya pemerintah untuk membantu petani meningkatkan produksi dan pendapatan padi yaitu dengan mengadakan program Peningkatan Produksi Beras Nasional (P2BN) merupakan upaya terkoordinasi dari pemerintah untuk membangun pertanian tangguh dengan memasyarakatkan teknologi dan inovasi baru.

Badan Pusat Statistik Provinsi Lampung tahun 2015, menjelaskan bahwa Kabupaten Lampung Tengah menjadi penghasil beras terbesar di Provinsi Lampung dan juga bisa dikatakan sebagai lumbung padi. Salah satu kecamatan yang mempunyai luasan lahan sawah terbesar ketiga di Kabupaten Lampung Tengah adalah Kecamatan Seputih Mataram. Kecamatan ini mempunyai 49 Kelompok Tani dan memiliki 1.617 anggota yang mayoritas petani padi sawah.

Keberhasilan sebuah program memerlukan partisipasi dalam bentuk keterlibatan petani pada kegiatan-kegiatan yang dijalankan. Partisipasi diartikan tidak hanya menyumbang tenaga, yaitu harus menyangkut dari taraf perencanaan, pelaksanaan dan pemanfaatan (Mubyarto 1989). Keberhasilan tujuan dari program ini tidak hanya mengandalkan peranan dari pemerintah saja, partisipasi petani juga berpengaruh terhadap tercapainya tujuan dari program, dengan mengetahui keterlibatan petani dalam Program tersebut maka diharapkan dapat mengetahui faktorfaktor yang mempengaruhi partisipasi petani padi dalam program P2BN.

Berdasarkan uraian tersebut, maka tujuan dari penelitian ini adalah mengetahui keragaan pelaksanaan program P2BN di Kecamatan Seputih Mataram Kabupaten Lampung Tengah, mengetahui tingkat partisipasi petani padi dalam program P2BN di Kecamatan Seputih Mataram Kabupaten Lampung Tengah dan mempelajari faktor-faktor apa saja yang berhubungan tingkat partisipasi petani padi dalam program P2BN di Kecamatan Seputih Mataram Kabupaten Lampung Tengah.

\section{METODE PENELITIAN}

Metode penelitian yang digunakan adalah metode survey. Penelitian ini dilakukan di Kecamatan Seputih Mataram, Kabupaten Lampung Tengah. Lokasi penelitian dipilih secara sengaja 


\section{JIIA, VOLUME 6, No. 1, FEBRUARI 2018}

(purposive) karena kecamatan tersebut memiliki luas lahan sawah terluas di Kabupaten Lampung Tengah. Pengambilan data dilakukan pada bulan November-Desember 2016. Populasi pada penelitian ini adalah anggota kelompok tani yang melaksanakan program P2BN yakni sebanyak 1.637. Sampel diambil secara alokasi Proportional random sampling atau menentuan sampel secara acak yakni sebanyak 95 responden.

Data yang digunakan dalam penelitian ini adalah data primer dan data sekunder. Data primer diperoleh secara langsung melalui wawancara serta pengamatan langsung pada petani padi dengan panduan kuesioner. Data sekunder diperoleh dari badan dan instansi terkait di daerah penelitian.

Peubah-peubah yang diduga berhubungan dengan Tingkat partisipasi petani adalah pengetahuan terhadap program P2BN, dukungan sosial, luas lahan garapan, tingkat pendapatan dan fasilitas yang diterima petani. Pengukuran peubah-peubah menggunakan teknik skoring dengan skor 1-3 yang diklasifikasikan ke dalam tiga kategori, sedangkan untuk variabel luas lahan garapan dan tingkat pendapatan tidak menggunakan teknik skoring.

Analisis data menggunakan metode deskriptif, sedangkan pengujian hipotesis menggunakan statistik nonparametrik korelasi Rank Spearman (Siegel 1994) dengan menggunakan Program SPSS 16. Data dalam bentuk skala ordinal diubah menjadi data interval dengan menggunakan metode MSI, sedangkan data tingkat pendapatan dan luas lahan garapan merupakan data rasio. Kaidah pengambilan keputusan sebagai berikut:

1. Jika nilai signifikan $\leq 0,05$ maka, dapat disimpulkan bahwa terdapat korelasi yang signifikan antara variabel.

2. Jika nilai signifikan $>0,05$ maka, dapat disimpulkan bahwa tidak terdapat korelasi yang signifikan antara variabel.

\section{HASIL DAN PEMBAHASAN}

\section{Keragaan Program Peningkatan Produksi Beras Nasional (P2BN)}

\section{Perencanaan Program P2BN}

Keragaan Program P2BN dalam tahap perencanaan ini berkaitan dengan penentuan alternatif petani yang berkaitan dengan gagasan atau ide yang menyangkut kepentingan Program dan petani. Kegiatan-kegiatan dalam perencanaan dilaksanakan dua bulan sebelum musim tanam untuk mengatur dan menetapkan jadwal musyawarah kelompok tani. Kegiatan pada tahap perencanaan antara lain adalah 1) penyusunan Rencana Definitif Kegiatan Kelompok (RDKK) yang dilakukan oleh seluruh anggota kelompok tani yang ikut dalam program P2BN dan PPL setempat. Kegiatan ini dilaksanakan di BP3K Kecamatan Seputih Mataram dari pukul 19.00 22.00. Kegiatan ini dihadiri oleh sebagian besar petani yang ikut serta dalam program P2BN. 2) pada kegiatan dalam mengidentifikasi masalah dilakukan dengan cara diskusi oleh PPL dan ketua dari masing-masing kelompok tani. Kegiatan ini dilakukan sekitar dua minggu sebelum tahap pelaksanaan dimulai.

\section{Pelaksanaan Program P2BN}

Keragaan program P2BN dalam tahap pelaksanaan ini berkaitan dengan mekanisme kegiatan langsung di lapangan, diantaranya 1) kegiatan pembagiaan benih hibrida sebanyak $15 \mathrm{Kg} / \mathrm{Ha}$ dilaksanakan di kediaman Bapak Pulung. 2) pembagian pupuk NPK sebanyak $150 \mathrm{Kg} / \mathrm{Ha}$ dan UREA sebanyak $200 \mathrm{Kg} / \mathrm{Ha}$, kegiatan ini juga dilaksanakan di kediaman Bapak Pulung, bersamaan dengan kegiatan pembagian benih Hibrida. Pada kegiatan pembagian pupuk ini dihadiri oleh seluruh petani yang ikut serta dalam program P2BN. 3) Kegiatan penyuluhan dilaksanakan di kantor BP3K Kecamatan Seputih Mataram yang dilakukan oleh penyuluh pertanian bertujuan untuk meningkatkan pemanfaatan ilmu pengetahuan dan teknologi pertanian, serta meningkatkan efisien dan produktivitas usaha tani. Kegiatan penyuluhan ini dilaksanakan sebanyak dua kali dalam satu bulan, namun dengan kendala kehadiran petani yang sedikit, kegiatan penyuluhan dikurangi menjadi satu kali dalam satu bulan. Pada kegiatan penyuluhan kehadiran petani yang terlibat dalam program dapat dikatakan sedikit, karena banyak petani yang tidak hadir dengan berbagai alasan. 4) kegiatan tanam serentak oleh para petani yang ikut serta dalam program P2BN. Kegiatan ini dilakukan oleh seluruh petani yang ikut serta dalam program $\mathrm{P} 2 \mathrm{BN}$.

\section{Evaluasi Program P2BN}

Pada tahap evaluasi ini berkaitan dengan masalah pelaksanaan program secara menyeluruh. Tahap ini bertujuan untuk mengetahui ketercapaian program yang telah direncanakan sebelumnya. Kegiatan-kegiatan yang terdapat pada tahap evaluasi antara lain adalah 1) Kegiatan 
pengawasan jalannya program, kegiatan ini dilakukan oleh penyuluh dan tim program P2BN yang dilaksanakan sebanyak tiga kali dari awal penanaman sampai panen dan seluruh kegiatan pengawasan ini berjalan dengan lancar, namun ada beberapa kendala yang dialami seperti jarak antar desa yang cukup jauh dan 2) pembuatan laporan pertanggungjawaban yang dilakukan oleh penyuluh dan anggota kelompok tani yang ikut dalam program P2BN untuk setiap desa, namun terdapat kendala pada kegiatan ini yaitu ketidakmampuan para peserta dalam pengoperasian laptop untuk membuat laporan.

\section{Pengambilan manfaat Program P2BN}

Pengambilan manfaat ini tidak lepas dari hasil pelaksanaan Program yang telah dicapai baik yang berkaitan dengan kuantitas maupun kualitas. Segi kualitas, hal ini dibuktikan dengan peningkatan dan perubahan produksi padi pada benih yang sudah dianjurkan oleh tim dari program P2BN. Pada segi kuantitas dibuktikan dengan persentase keberhasilan Program yaitu adopsi petani dari inovasi yang diberikan dari program P2BN.

Secara kesuluruhan kegiatan Pelaksanaan program P2BN dari tahap perencanaan sampai tahap evaluasi berjalan dengan lancar dan tidak terdapat kendala yang berarti, hanya saja bantuan benih yang diberikan dibatasi hanya untuk lahan seluas 0,25 Ha saja, sehingga produksi tidak maksimal.

\section{Deskripsi Variabel Faktor-faktor yang Berhubungan dengan Partisipasi Petani Padi dalam Pelaksanaan Program P2BN}

\section{Pengetahuan Terhadap Program P2BN}

Pengetahuan terhadap program mempunyai pengaruh cukup besar dalam menunjang responden untuk ikut serta dalam berbagai kegiatan dalam program $\mathrm{P} 2 \mathrm{BN}$, namun masih banyak responden yang kurang mengerti tetang program P2BN. Sebaran pengetahuan terhadap program dapat dilihat pada Tabel 1 .

Tabel 1 menunjukkan bahwa sebesar 49,48 persen responden berada pada klasifikasi tinggi dan sebesar 43,15 persen responden berada pada klasifikasi sedang. Kondisi ini merupakan potensi untuk meningkatkan partisipasi petani padi dalam kegiatan program $\mathrm{P} 2 \mathrm{BN}$, namun ada beberapa responden yang menganggap program sebagai bantuan dari pemerintah yaitu 7,37 persen responden pada klasifikasi rendah.
Tabel 1. Sebaran jumlah responden berdasarkan pengetahuan terhadap Program P2BN

\begin{tabular}{cccc}
\hline $\begin{array}{c}\text { Interval } \\
\text { (skor) }\end{array}$ & Klasifikasi & $\begin{array}{c}\text { Jumlah } \\
\text { (orang) }\end{array}$ & $\begin{array}{c}\text { Persentase } \\
(\%)\end{array}$ \\
\hline $4,00-7,35$ & Rendah & 7 & 7,37 \\
$7,36-10,7$ & Sedang & 41 & 43,15 \\
$10,71-14,06$ & Tinggi & 47 & 49,48 \\
\hline Jumlah & & 95 & 100,00 \\
\hline Rata-rata & 9,95 (sedang) & & \\
\hline
\end{tabular}

\section{Dukungan Sosial}

Dukungan sosial adalah dukungan atau bantuan yang diberikan oleh orang lain yang memiliki hubungan sosial atau yang akrab dengan individu lain. Hasil Penelitian ini menunjukkan responden yang menerima dukungan sosial. Sebaran dukungan sosial dapat dilihat pada Tabel 2 .

Tabel 2 menunjukkan bahwa presentase terbesar masuk pada klasifikasi sedang sebesar 47,37 persen. Hal ini dikarenakan ada beberapa respoden yang berperan aktif dan ada yang pasif dalam kegiatan program P2BN, dengan keaktifannya dalam mengikuti kegiatan akan membuat orangorang disekitarnya memberikan dukungan sosial, agar dapat meningkatkan partisipasi petani dalam program $\mathrm{P} 2 \mathrm{BN}$.

\section{Luas Lahan Garapan}

Luas lahan garapan adalah luas lahan yang digarap petani untuk tanaman padi. Hasil Penelitian ini menunjukkan bahwa sebagian besar luas lahan garapan yang dimiliki responden masuk dalam klasifikasi sempit. Sebaran luas lahan garapan dapat dilihat pada Tabel 3. Tabel 3 menunjukkan bahwa sebagian besar yaitu 77,90 persen berada di klasifikasi sempit. Hal ini disebabkan banyak yang membagi lahan garapannya untuk keluarganya. Kondisi ini tidak mempengaruhi petani untuk meningkatkan produksi dan meningkatkan partisipasi. Pada penelitian ini seluruh luas lahan garapan dikonversikan menjadi $1 \mathrm{Ha}$, dengan tujuan untuk melihat perbedaan tingkat pendapatan antar responden.

Tabel 2. Sebaran jumlah responden berdasarkan dukungan sosial

\begin{tabular}{cccc}
\hline $\begin{array}{c}\text { Interval } \\
\text { (skor) }\end{array}$ & Klasifikasi & $\begin{array}{c}\text { Jumlah } \\
\text { (orang) }\end{array}$ & $\begin{array}{c}\text { Persentase } \\
(\%)\end{array}$ \\
\hline $3,00-5,36$ & Rendah & 33 & 34,73 \\
$5,37-7,72$ & Sedang & 45 & 47,37 \\
$7,73-10,09$ & Tinggi & 17 & 17,90 \\
\hline Jumlah & & 95 & 100,00 \\
\hline Rata-rata & 6,43 (sedang) & & \\
\hline
\end{tabular}


Tabel 3. Sebaran jumlah responden berdasarkan luas lahan garapan

\begin{tabular}{cccc}
\hline $\begin{array}{c}\text { Interval } \\
(\mathrm{Ha})\end{array}$ & Klasifikasi & $\begin{array}{c}\text { Jumlah } \\
\text { (orang) }\end{array}$ & $\begin{array}{c}\text { Persentase } \\
(\%)\end{array}$ \\
\hline$<0,5$ & Sempit & 74 & 77,90 \\
$>0,5-<0,75$ & Sedang & 18 & 18,95 \\
$\geq 0,75$ & Luas & 3 & 3,15 \\
\hline Jumlah & & 95 & 100,00 \\
\hline Rata-rata & 0,32 (sempit) & \\
\hline
\end{tabular}

\section{Fasilitas yang Diterima Petani}

Fasilitas yang diterima petani adalah sejumlah barang atau jasa yang diberikan oleh program P2BN untuk petani. Hasil Penelitian ini menunjukkan bahwa fasilitas yang diterima petani di Kecamatan Seputih Mataram tidak sepenuhnya diterima oleh petani. Sebaran fasilitas yang diterima petani yang disajikan pada Tabel 4 menunjukkan bahwa sebagian besar responden berada diklasifikasi tinggi yaitu 75,79 persen. Karena bantuan yang diberikan oleh program P2BN terbatas, bantuan yang diterima petani seperti pupuk dan benih tidak maksimal, hanya untuk lahan seluas 0,25 Ha. Kondisi ini membuat produksi padi tidak maksimal, namun dengan adanya bantuan yang diberikan untuk petani dapat meningkatkan partisipasi petani padi dalam pelaksanaan program $\mathrm{P} 2 \mathrm{BN}$ dan juga dapat meningkatkan pendapatan usahatani.

\section{Deskripsi Tingkat Partisipasi Petani dalam Pelaksanaan Program P2BN}

Newstrom (2004) mengatakan bahwa partisipasi adalah keterlibatan mental dan emosional orangorang dalam situasi kelompok dan mendorong mereka untuk memberikan suatu kontribusi demi tujuan kelompok, dan juga berbagai tanggung jawab dalam pencapaian tujuan. Demikian juga halnya keterlibatan mental dan emosional anggota kelompok tani di Kecamatan Seputih Mataram Lampung Tengah dalam menjalankan kegiatankegiatann Program P2BN. Secara kesuluruhan tingkat partisipasi petani dalam pelaksanaan program P2BN dapat dilihat pada Tabel 5.

Tabel 4. Sebaran responden berdasarkan fasilitas yang diterima petani

\begin{tabular}{cccc}
\hline $\begin{array}{c}\text { Interval } \\
\text { (skor) }\end{array}$ & Klasifikasi & $\begin{array}{c}\text { Jumlah } \\
\text { (orang) }\end{array}$ & $\begin{array}{c}\text { Persentase } \\
(\%)\end{array}$ \\
\hline $2,00-3,13$ & Rendah & 23 & 24,21 \\
$3,14-4,47$ & Sedang & 0 & 0,00 \\
$4,28-5,41$ & Tinggi & 72 & 75,79 \\
\hline Jumlah & & 95 & 100,00 \\
\hline Rata-rata & 4,58 (sedang) & & \\
\hline
\end{tabular}

Tabel 5 menunjukkan bahwa sebagian besar tingkat partisipasi petani dalam pelaksanaan program P2BN berada pada klasifikasi sedang sebesar 76,84 persen, pada klasifikasi tinggi sebesar 7,37 persen, artinya petani sudah mempunyai kemauan untuk ikut serta atau berpartisipasi dalam program $\mathrm{P} 2 \mathrm{BN}$, walaupun masih ada responden yang masuk kedalam klasifikasi rendah yaitu sebesar 15,79 persen responden

\section{Partisipasi dalam Perencanaan Program P2BN}

Partisipasi dalam perencanaan adalah partisipasi petani dalam kegiatan-kegiatan pada tahap perecanaan program P2BN. Tingkat partisipasi petani dalam perencanaan program $\mathrm{P} 2 \mathrm{BN}$ dapat dilihat pada Tabel 6 .

Tabel 6 menunjukkan bahwa sebagian besar parisipasi petani dalam perencanaan program P2BN berada pada klasifikasi sedang yaitu 77,89 persen, pada klasifikasi tinggi sebesar 8,41 persen, dan 13,69 persen berada pada klasifikasi rendah. Banyak responden yang tidak mengikuti kegiatan rapat, dikarenakan kegiatan-kegiatan yang ada dalam perencaan program P2BN dilaksanakan pada malam hari, hal ini yang membuat banyak responden tidak dapat mengikuti kegiatan, karena digunakan untuk beristirahat.

Tabel 5. Sebaran keseluruhan tingkat partisipasi petani dalam program $\mathrm{P} 2 \mathrm{BN}$

\begin{tabular}{cccc}
\hline Selang (skor) & Klasifikasi & $\begin{array}{c}\text { Jumlah } \\
\text { (orang) }\end{array}$ & $\begin{array}{c}\text { Persentase } \\
(\%)\end{array}$ \\
\hline $24,111-34,428$ & Rendah & 15 & 15,79 \\
$34,429-44,745$ & Sedang & 73 & 76,84 \\
$44,746-55,062$ & Tinggi & 7 & 7,37 \\
\hline Jumlah & & 95 & 100,00 \\
\hline Rata-rata & 38,91 (sedang) & & \\
\hline
\end{tabular}

Tabel 6. Sebaran berdasarkan partisipasi pada perencanaan program $\mathrm{P} 2 \mathrm{BN}$

\begin{tabular}{cccc}
\hline Interval (skor) & Klasifikasi & $\begin{array}{c}\text { Jumlah } \\
\text { (orang) }\end{array}$ & $\begin{array}{c}\text { Persentase } \\
(\%)\end{array}$ \\
\hline $4,00-8,49$ & Rendah & 13 & 13,69 \\
$8,50-12,99$ & Sedang & 74 & 77,89 \\
$13,00-17,49$ & Tinggi & 8 & 8,42 \\
\hline Jumlah & & 95 & 100,00 \\
\hline Rata-rata & 10,74 (sedang) & & \\
\hline
\end{tabular}




\section{Partisipasi dalam Pelaksanaan Progran P2BN}

Partisipasi dalam pelaksanaan adalah partisipasi petani dalam kegiatan-kegiatan yang ada pada pelaksanaan program P2BN. Partisipasi dalam pelaksanaan seperti kehadiran petani, kegiatan rapat rutin, kegiatan penyuluhan, pembagiaan benih hibrida, dan pembagian pupuk. Tingkat partisipasi responden dalam pelaksanaan program P2BN dapat dilihat pada Tabel 7.

Tabel 7 menunjukkan bahwa sebagian besar partisipasi petani dalam pelaksanaan program

P2BN masuk dalam klasifikasi sedang yaitu sebesar 74,73 persen, hal ini disebabkan masih banyak responden yang tidak mengikuti kegiatan seperti rapat atau penyuluhan, namun untuk kegiatan pembagian pupuk dan benih seluruh responden menghadiri dan menerima bantuan yang diberikan oleh program. Secara keseluruhan dapat dikatakan petani berpartisipasi cukup aktif dalam mengikuti kegiatan-kegiatan program P2BN.

\section{Partisipasi dalam Evaluasi}

Partisipasi dalam evaluasi adalah keterlibatan petani dalam penilaian program $\mathrm{P} 2 \mathrm{BN}$, seperti kegiatan dalam pengawasan jalannya program, pembuatan laporan pertanggungjawaban dan pemberian penilaian terhadap program $\mathrm{P} 2 \mathrm{BN}$. Seberan tingkat partisipasi responden dalam evaluasi dapat dilihat pada Tabel 8 .

Tabel 7. Sebaran berdasarkan partisipasi pada pelaksanaan program $\mathrm{P} 2 \mathrm{BN}$

\begin{tabular}{cccc}
\hline Interval (skor) & Klasifikasi & $\begin{array}{c}\text { Jumlah } \\
\text { (orang) }\end{array}$ & $\begin{array}{c}\text { Persentase } \\
(\%)\end{array}$ \\
\hline $7,67-11,39$ & Rendah & 11 & 11,58 \\
$11,40-15,12$ & Sedang & 71 & 74,73 \\
$15,13-18,86$ & Tinggi & 13 & 13,69 \\
\hline Jumlah & & 95 & 100,00 \\
\hline Rata-rata & 13,01 (sedang) & & \\
\hline
\end{tabular}

Tabel 8. Sebaran berdasarkan partisipasi dalam evaluasi program $\mathrm{P} 2 \mathrm{BN}$

\begin{tabular}{cccc}
\hline Interval (skor) & Klasifikasi & $\begin{array}{c}\text { Jumlah } \\
\text { (orang) }\end{array}$ & $\begin{array}{c}\text { Persentase } \\
(\%)\end{array}$ \\
\hline $7.67-10,67$ & Rendah & 11 & 11,57 \\
$10,68-13,71$ & Sedang & 64 & 67,37 \\
$13,72-16,72$ & Tinggi & 20 & 21,06 \\
\hline Jumlah & & 95 & 100,00 \\
\hline Rata-rata & 13.37 (sedang) & & \\
\hline
\end{tabular}

Tabel 8 menunjukkan bahwa partisipasi petani dalam evaluasi, petani berpartisipasi pasif dalam mengikuti kegiatan-kegiatan yang ada dalam evaluasi program P2BN. Namun masih ada petani yang masuk ke dalam klasifikasi rendah, hal ini dikarenakan pada kegiatan-kegiatan seperti pembuatan laporan pertanggujawaban masih ada responden yang tidak mengikuti dan tidak bisa mengoperasikan laptop untuk membuat laporan pertanggungjawaban. Secara keseluruhan responden masuk kedalam klasifikasikan sedang dengan hasil rata-rata 13,37.

\section{Partisipasi dalam Pengambilan Manfaat pada Program P2BN}

Partisipasi dalam pengambilan manfaat adalah partisipasi petani dalam mengambil manfaat yang didapat dari kegiatan-kegiatan dalam program P2BN, pengambilan manfaat seperti peningkatan dan perubahan yang dialami petani dalam satu musim tanam. Sebaran responden dalam pengambilan manfaat dapat dilihat pada Tabel 9.

Tabel 9 menunjukkan bahwa hampir seluruhnya responden masuk kedalam klasifikasikan rendah 97,89 persen. Berdasarkan hasil di lapangan partisipasi petani yang ikut serta dalam program P2BN ini kurang begitu besar dikarenakan, banyak petani yang ikut hanya untuk memperoleh bantuan saja, bukan untuk mencari ilmu pengetahuan baru atau tegnologi baru dalam berusaha tani.

Tabel 9. Sebaran berdasarkan partisipasi dalam pengambilan manfaat

\begin{tabular}{cccc}
\hline Interval (skor) & Klasifikasi & $\begin{array}{c}\text { Jumlah } \\
\text { (orang) }\end{array}$ & $\begin{array}{c}\text { Persentase } \\
(\%)\end{array}$ \\
\hline $2.00-3,64$ & Rendah & 93 & 97,89 \\
$3,65-5,27$ & Sedang & 0 & 0,00 \\
$5,28-6,90$ & Tinggi & 2 & 2,11 \\
\hline Jumlah & & 95 & 00,00 \\
\hline Rata-rata & 2,10(rendah) & \\
\hline
\end{tabular}

Tabel 10. Hasil analisis variabel bebas (X) dengan variabel $(\mathrm{Y})$

\begin{tabular}{lccc}
\hline \multicolumn{1}{c}{ Variabel X } & Variabel Y & Corelation & $\begin{array}{c}\text { Sig (2- } \\
\text { tailed) }\end{array}$ \\
\hline - Pengetahuan & Partisipasi & $0,415^{* *}$ & 0,000 \\
terhadap Program & & \\
- Dukungan sosial & $\begin{array}{c}\text { Petani dalam } \\
\text { - Luas lahan }\end{array}$ & $0,314^{* *}$ & 0,002 \\
$\quad$ Parapan & $-0,081^{\text {th }}$ & 0,437 \\
- Fasilitas yang & & & \\
$\quad$ diterima Petani & & $-0,019^{\text {th }}$ & 0,856 \\
$\begin{array}{l}\text { Keterangan : } \\
\text { ** : Berhubungan sangat nyata pada taraf kepercayaan } 99 \%\end{array}$ \\
tn : Tidak nyata
\end{tabular}




\section{Pengujian Hipotesis}

Hubungan antara variabel $\mathrm{X}$ (pengetahuan terhadap program $\mathrm{P} 2 \mathrm{BN}$, dukungan sosial, luas lahan garapan, tingkat pendapatan dan fasilitas yang diterima petani) dengan variabel $\mathrm{Y}$ (partisipasi petani dalam perencanaan, partisipasi dalam pelaksanaan, partisipasi dalam pengambilan manfaat dan partisipasi dalam evaluasi) dianalisis dengan menggunakan statistika non parametrik uji korelasi Rank Spearman yang dilanjutkan uji t. Hasil pengujian secara statistik terhadap faktorfaktor yang berhungan dengan partisipasi responden dalam program $\mathrm{P} 2 \mathrm{BN}$ dapat dilihat pada Tabel 10.

Tabel 10 menunjukkan bahwa veriabel-variabel yang berhubungan nyata dengan partisipasi petani dalam pelaksanaan program $\mathrm{P} 2 \mathrm{BN}$ adalah pengetahuan terhadap program dan dukungan sosial, sedangkan variabel yang tidak berhubungan nyata terhadap partisipasi petani dalam pelaksanaan program P2BN adalah luas lahan garapan, tingkat pendapatan dan fasilitas yang diterima petani. Berikut ini adalah uraian masingmasing variabel

\section{Hubungan antara pengetahuan terhadap Program P2BN dengan tingkat partisipasi petani padi dalam pelaksanaan Program P2BN}

Berdasarkan uji statistik antara pengetahuan terhadap program $\mathrm{P} 2 \mathrm{BN}$ dengan partisipasi petani dalam pelaksanaan program $\mathrm{P} 2 \mathrm{BN}$ diperoleh nilai korelasi rank spearman sebesar 0,415 dengan nilai signifikansi sebesar 0,000 . Nilai signifikansi tersebut lebih kecil dibandingkan nilai $\alpha(0,05)$ dengan tingkat kepercayaan 99 persen, sehingga dapat diambil keputusan untuk menolak $\mathrm{H}_{0}$ dan terima $\mathrm{H}_{1}$, yaitu terdapat hubungan nyata antara pengetahuan terhadap program dengan partisipasi petani dalam pelaksanaan program $\mathrm{P} 2 \mathrm{BN}$.

Hasil penelitian di lapangan menunjukkan bahwa pengetahuan responden terhadap program P2BN termasuk dalam klasifikasi tinggi dengan presentase sebesar 49,48 persen. Berdasarkan uraian Tabel 11 di atas dapat disimpulkan bahwa semakin petani memahami tentang suatu program, partisipasi petani akan semakin tinggi karena dari data yang diperoleh di lapangan dengan petani memahami suatu program, petani akan menerima manfaat seperti inovasi baru tentang berusahatani dan dapat membantu petani dalam memberi solusi untuk masalah-masalah yang dihadapi dalam berusahatani.
Hubungan antara dukungan sosial dengan tingkat partisipasi petani dalam pelaksanaan Program P2BN

Berdasarkan uji statistik antara dukungan sosial dengan partisipasi petani dalam pelaksanaan program P2BN diperoleh nilai korelasi rank spearman sebesar 0,314 dengan nilai signifikansi sebesar 0,002. Nilai signifikansi tersebut lebih kecil dibandingkan nilai $\alpha(0,05)$ dengan tingkat kepercayaan 99 persen, sehingga dapat diambil keputusan untuk menolak $\mathrm{H}_{0}$ dan terima $\mathrm{H}_{1}$, yaitu terdapat hubungan nyata antara dukungan sosial dengan partisipasi petani dalam pelaksanaan program $\mathrm{P} 2 \mathrm{BN}$.

Hasil penelitian di lapangan menunjukkan bahwa dukungan sosial yang diterima respoden termasuk dalam klasifikasi sedang dengan presentase sebesar 47,37 persen. Keadaan ini menunjukan bahwa dukungan sosial berhubungan erat dengan partisipasi petani dalam pelaksanaan program P2BN, artinya dukungan sosial yang didapat petani dari keluarga seperti membantu dalam berusahatani, dari anggota kelompok lain seperti ajakan atau tukar informasi dan dari PPL seperti bimbingan dalam berusahatani atau memotivasi berhubungan dengan partisipasi petani dalam pelaksanaan program $\mathrm{P} 2 \mathrm{BN}$, dengan tingginya dukungan sosial yang diterima oleh petani akan meningkatkan partisipasi petani dalam pelaksanaan program P2BN.

\section{Hubungan antara luas lahan garapan dengan tingkat partisipasi petani dalam pelaksanaan Program P2BN}

Berdasarkan uji statistik antara luas lahan garapan dengan partisipasi petani dalam pelaksanaan program P2BN diperoleh nilai korelasi rank spearman sebesar 0,081 dengan nilai signifikansi sebesar 0,437. Nilai signifikansi tersebut lebih besar dibandingkan nilai $\alpha(0,05)$, sehingga dapat diambil keputusan untuk menolak $\mathrm{H}_{1}$ dan terima $\mathrm{H}_{0}$, yaitu tidak terdapat hubungan nyata antara luas lahan garapan dengan partisipasi petani dalam pelaksanaan program $\mathrm{P} 2 \mathrm{BN}$.

Hasil penelitian di lapangan menunjukkan bahwa luas lahan garapan termasuk dalam klasifikasi sempit dengan presentase sebesar 77,90 persen. Berdasarkan hasil pengamatan di lapangan dapat dilihat bahwa luas lahan garapan merupakan faktor yang tidak berhubungan dengan partisipasi petani dalam pelaksanaan program $\mathrm{P} 2 \mathrm{BN}$, dikarenakan seluruh bantuan yang diberikan oleh program 


\section{JIIA, VOLUME 6, No. 1, FEBRUARI 2018}

P2BN bersifat merata yaitu pemberian bantuan untuk lahan seluas $0,25 \mathrm{Ha}$, sehingga berapapun luas lahan garapan yang dimiliki tidak mempengaruhi jumlah bantuan yang diberikan oleh program P2BN. Hasil penelitian ini sesuai dengan penelitiaan (Metylia 2007) yang menjelaskan bahwa luas lahan garapan tidak berhubungan nyata terhadap partisipasi anggota KUD tanggamus Kecamatan Talang Padang Kabupaten Lampung Selatan.

\section{Hubungan antara fasilitas yang diterima petani dengan tingkat partisipasi petani dalam pelaksanaan Program P2BN}

Berdasarkan uji statistik antara fasilitas yang diterima petani dengan tingkat partisipasi petani dalam pelaksanaan program $\mathrm{P} 2 \mathrm{BN}$ diperoleh nilai korelasi rank spearman sebesar 0,019 dengan nilai signifikansi sebesar 0,856 . Nilai signifikansi tersebut lebih besar dibandingkan nilai $\alpha(0,05)$, sehingga dapat diambil keputusan untuk menolak $\mathrm{H}_{1}$ dan terima $\mathrm{H}_{0}$, yaitu tidak terdapat hubungan nyata antara fasilitas yang diterima petani dengan tingkat partisipasi petani dalam pelaksanaan program $\mathrm{P} 2 \mathrm{BN}$.

Berdasarkan hasil pengamatan di lapangan dapat dilihat bahwa banyaknya fasilitas yang diterima petani bukan berarti partisipasi petani dalam program $\mathrm{P} 2 \mathrm{BN}$ akan tinggi, karena fasilitas yang diberikan oleh program P2BN berupa benih, pupuk dan penyuluhan bersifat merata terhadap semua petani. Tingginya partisipasi petani dalam suatu program, petani akan mendapatkan banyak manfaat seperti memperoleh inovasi baru dalam berusahatani, meringankan beban petani dalam menyediakan sarana dalam berusahatani, mangurangi besarnya modal yang akan dikeluarkan petani dan memberi solusi untuk masalah-masalah yang dikeluhkan petani dalam berusahatani.

\section{KESIMPULAN}

Berdasarkan hasil penelitian, keragaan pada pelaksanaan program P2BN sudah berjalan dengan baik, tingkat partisipasi petani dalam program P2BN termasuk pada kategori sedang, dan terdapat hubungan yang nyata antara pengetahuan terhadap program P2BN dan dukungan sosial dengan partisipasi petani dalam pelaksanaan program P2BN, sedangkan luas lahan garapan, tingkat pendapatan dan fasilitas yang diterima petani tidak berhubungan terhadap partisipasi petani.

\section{DAFTAR PUSTAKA}

Badan Pusat Statistik. 2015. Produksi, Luas Panen Dan Paroduktivitas Padi. Lampung.

Badan Pusat Statistik. 2015. Luasan Lahan Padi Sawah. Lampung Tengah.

Balai Penyuluhan Pertanian Perikanan dan Kehutanan. 2012. Juklak Demfarm Padi. Lampung Tengah.

Balai Penyuluhan Pertanian Perikanan dan Kehutanan. 2015. Data Kelompok Tani Penerima Bantuan Benih Hibrida. Kecamatan Seputih Mataram. Lampung Tengah.

Batubara RH, Effendi I, dan Prayitno RT. 2016. Partisipasi masyarakat dalam program gerakan serentak membangun kampung (GSMK) di Kecamatan Gedung Aji Baru Kabupaten Tulang Bawang. JIIA, 4 (1): 111117. http://jurnal.fp.unila.ac.id/index.php/JIA /article/view/1221/1118. [2 Oktober 2017].

Metylia. 2007. Partisipasi Masyarakat Dalam Program Gerakan Pembangunan (Gerbang) Bagui Jejamo Wawai (BJW) Tahun Anggaran 2005 di Kecamatan Bumi Nabung Kecamatan Lampung Tengah. Skripsi. Universitas Lampung. Lampung.

Mubyarto. 1989. Pengantar Ekonomi Pertanian. Lembaga Penelitian Pendidikan dan Penerangan Ekonomi dan Sosial. Jakarta.

Newstrom. 2004. Prilaku dalam Organisasi, Edisi 7 Bahasa Indonesia, Jilid 1. Erlangga. Jakarta.

Rizal M dan Rahayu SP. 2015. Tingkat Partisipasi petani dalam kelompok tani padi sawah untuk mendukung program M-P3MI di Kabupaten Paser Kalimantan Timur. Jurnal Agribisnis dan Agrowisata, 1 ( 2): 352-357. http://biodiversitas.mipa.uns.ac.id/M/M 0102/ M010231.pdf. [2 Oktober 2017].

Siegel S. 1994. Statistik Non Parametrik. Diterjemahkan oleh Zanzawi Suyuti dan Landung Simatupang. Gramedia. Jakarta.

Widianti E, Gitosaputro S, dan Yanfika H. 2015. Kebutuhan dan partisipasi masyarakat dalam program kemitraan dan bina lingkungan (PKBL) PTPN7 Unit Usaha Rejosari Kecamatan Natar Kabupaten Lampung Selatan. JIIA, 3 (2): 195-202. http://jurnal. fp. unila.ac.id/index.php/JIA/article/view/1039/9 44. [2 Oktober 2017]. 